\title{
Sustainability and Competitiveness of Logistics Services Providers in Indonesia
}

\author{
Engkos Achmad Kuncoro ${ }^{1 *}$; Dony Saputra²; Robin Cahyadi; Ridho Bramulya Ikhsan ${ }^{4}$ \\ ${ }^{1-3}$ Management Department, BINUS Business School Undergraduate Program, Bina Nusantara University \\ Jln. K. H. Syahdan No. 9, Jakarta Barat 11480, Indonesia \\ ${ }^{4}$ Management Department, BINUS Online Learning, Bina Nusantara University \\ Jln. K. H. Syahdan No. 9, Jakarta Barat 11480, Indonesia \\ 1'eak@binus.edu; ${ }^{2}$ dsaputra@binus.edu; ${ }^{3}$ robin.cahyadi@binus.ac.id; ${ }^{4}$ Ridho.ikhsan@binus.edu
}

Received: $6^{\text {th }}$ October 2021/ Revised: $19^{\text {th }}$ October 2021/ Accepted: $21^{\text {st }}$ October 2021

How to Cite: Kuncoro, E. A., Saputra, D., Cahyadi, R., \& Ikhsan, R. B. (2021). Sustainability and Competitiveness of Logistics Services Providers in Indonesia. Binus Business Review, 12(3), 279-287. https://doi.org/10.21512/bbr.v12i3.7783

\begin{abstract}
With the rise of competition and challenges for Logistics Service Providers (LSP) in Indonesia, competitiveness and sustainability are needed. The research explored logistical process and identified factors that built the competitiveness of LSP, such as Third-Party Logistics (3PL) in Indonesia. The research also identified factors and relationships of their competitiveness and sustainability. The research method was explorative with a qualitativeobservation approach. The applied sampling technique was purposive and snowball. The participants were 10 LSP operating in Indonesia: Kühne + Nagel, FedEx, Damco, DB Schenker, APL Logistics, Panalpina, Agility Logistics, TNT Express, Röhlig Logistic, and Rhenus Logistic. The data were unstructured interviews with 10 middle managers with the job position of leader and manager. Then, the data were analyzed using NVivo 10 software. The result is the recommendation of the competitiveness model for 3PL that the providers can apply to achieve its sustainability. Moreover, the factors that drive competitiveness of LSP are price, service, people, and network. Meanwhile, innovation and credibility improve competitiveness toward sustainability of 3PL. Based on the findings, it can offer opportunities for further research on the relationship and influence of these variables on other similar companies in other countries.
\end{abstract}

Keywords: sustainability, competitiveness, Logistics Services Providers (LSP)

\section{INTRODUCTION}

Based on Burnson (2017), there is a significant growth in Third-Party Logistics (3PL) provider revenue, with the technology industry as the largest industry that contributes revenue to the 3PL provider. Moreover, the automotive and retail industry sectors are the second and third largest contributing revenue to the 3PL provider. The income of 3PL providers each year has increased significantly and is expected to continue to increase in the coming years. Compared to Allied Market Research (2020), the 3PL provider of transportation mode was dominated by land route as the main one, followed by sea and train routes.

The Logistic Performance Index (LPI) published in 2018 by The World Bank (2018) reported that Indonesia's LPI had a score of 3,15 and was $5^{\text {th }}$ in
ASEAN and $46^{\text {th }}$ in the world. Two years ago, Indonesia was perched at $63 \mathrm{rd}$ position in the world. Moreover, Indonesia Economic Forum (2020) predicted that the logistic market revenues forecast in 2020 were US\$220,9 billion. Based on that enormous potential, many providers are competing to offer the best and most complete logistics services to take and control the logistics market in Indonesia. Many 3PL providers are now dividing their markets into several segments, from transportation modes, services to the regional division.

In Indonesia, the challenge of infrastructure is still the main obstacle for the 3PL providers. They must anticipate damaged roads and the lack of ports for logistic docking. Another problem is getting closer to consumers through various methods. However, the providers can expand their network to meet all 
consumers' needs and build an integrated and spread system throughout Indonesia. Besides, providers need to understand consumers' in-depth behavior. Understanding this consumer behavior can be done by conducting various research on what consumers need and need in Indonesia today (Zaroni, 2017).

According to Indonesian Logistics and Forwarders Association (ALFI), in 2020, around 3.412 local logistics companies operating in Indonesia, there were only $1 \%$ or around 36 companies that could have or had sufficient competitiveness with foreign logistics companies that $93 \%$ of them were local logistic companies with Small and Medium Scale Enterprises (SMEs) (Lestarini, 2021). It shows that the foreign logistics companies' competencies are higher and can empower local logistics companies. Besides high competitiveness, the volume of logistics services held by foreign companies also increases compared to local companies, which are declining. This inadequate competence should be a concern of the government to focus on improving these local logistics companies' competencies. Besides, as a local logistics services company, it should have more competitiveness against foreign logistics companies to compete in the Indonesian logistics market. Considering the importance of consumers in this industry, logistics service companies, both local logistics companies and foreign logistics companies, are required to provide service quality and are balanced with high competitiveness to compete with their competitors. It can improve the increased competitiveness through maintaining competitiveness sustainably.

According to Ding and Jie (2021) and Huo, Wang, Zhao, and Hua (2017), 3PL provides one or many logistics-related services used by consumers. They can facilitate the transfer of parts and materials from suppliers to manufacturing and final and finished goods from manufacturing to be distributed to retail stores. Moreover, based on Jha, Aggarwal, and Singh (2020), outsourced logistics services are typically provided on a "third-party" basis, with the first party being the consignor, the second party being the consignee (customer), and the third party being the Logistics Service Providers (3PL). 3PL is in charge of the physical transfer of products or services between the consignor and consignee (customer). Meanwhile, according to Fabregas (2018), 3PL handles procurement, transportation, and distribution for client providers. Some 3PL services focus on specific segments, such as the procurement of products or shipping goods. Others fill several needs, such as warehousing and distribution to end-users. It can be concluded that 3PL is a Logistics Service Providers (LSP) offering services to another provider. The services range from loading and unloading of goods, warehousing, goods distribution, document management, and arrangements of transportation options.

Min and Jong Joo (2006) and Cavaignac, Dumas, and Petiot (2020) found that the competition did not always come from the whole Logistics Service Providers (LSP). Moreover, Langley Jr et al. (2007) and Langley $\mathrm{Jr}$ (2019) stated that many users were not satisfied with LSPs services because of three aspects: cost reduction, loss of public trust, and increasing needs for a more comprehensive portfolio of logistics services, geographical coverage, and advanced information technology. Then, Gong, Kung, and Zeng (2018), Langley Jr et al. (2007), and Langley Jr (2019) also mentioned that it had an impact on the logistics service rental period of only two years and only transportation and warehouse services. Therefore, theories and solutions are needed by the logistics services sector to achieve a sustainable competitive advantage.

Previous logistics studies have suggested that some company resources, such as physical, technological, and managerial competencies, can help explain logistics performance (Choi \& Song, 2018; Aziz, 2017; Alshawi, 2001; Bienstock, Royne, Sherrell, \& Stafford, 2008; Myers, Griffith, Daugherty, $\&$ Lusch, 2004). Based on previous research, service providers are often ignored in many studies related to user's resources. Research of provider resource perspective is needed to increase understanding of LSP competitive advantage (Elzarka, 2020; Ellinger, Ketchen Jr, Hult, Elmadağ, \& Richey Jr, 2008; Gunasekaran \& Ngai, 2003; Panayides, 2007). Indirectly, research like the mentioned one can help the ability of logistics services to contribute to LSP market share (Uvet, 2020; Daugherty, Stank, \& Ellinger, 1998).

There are three purposes of the research. First, it explains the logistics condition in Indonesia. Second, it identifies the factors that build competitiveness in foreign 3PL in Indonesia. Third, it analyzes the factor and relationship between competitiveness and sustainability.

\section{METHODS}

The research applies an explorative method with the qualitative-observation approach. The data source is the foreign LSP operating in Indonesia for more than five years. The sampling technique is purposive and snowball because the samples are taken by special consideration with a particular population in an interconnected network. The participants are 10 LSP operating in Indonesia: Kühne + Nagel, FedEx, Damco, DB Schenker, APL Logistics, Panalpina, Agility Logistics, TNT Express, Röhlig Logistic, and Rhenus Logistic. The data are collected by unstructured interviews with 10 middle managers with the job position of leader and manager.

Based on the results of the interview written in a narrative format, coding is done. The research uses result of the coding as a theme to formulate categories. This process is carried out using NVivo coding with the approach by Miles, Huberman, and Saldana (2013). 


\section{RESULTS AND DISCUSSIONS}

The research presents company case study analysis and key findings of the three research questions: the condition of LSP in Indonesia, competitiveness factor of LSP, and factors that relate the competitiveness with its sustainability. There are 10 informants from foreign 3PL provides with criteria of the middle (managers) to top management (country head) and experience of more than five years. Data analysis is divided into three activity processes: data reduction, presentation, and drawing conclusions or verification (Miles et al., 2013). The information for each LSP is collected through from its company's website .

Table 1 summarizes the triangulation of responses from ten informants on the factors that influence the competitiveness and sustainability of 3PL logistics service providers. The factors that affect competitiveness are prices approved by $80 \%$ of informants, services by $90 \%$ of informants, humans by $50 \%$ of informants, and networks by $60 \%$ of informants. Meanwhile, $60 \%$ of the informants agree that the factors that affect sustainability are credibility and innovation.

The first case study is Kühne + Nagel in Indonesia. Since 1987, Kuehne + Nagel (KN) Indonesia has been established and developed in Asia. KN has several advantages, such as connecting people to the entire world through its extensive global network, having a complete track record (portfolio) in logistics for all major industries with sea and air freight, customs houses brokerage, and having contract logistics that focuses on integrated IT-based logistics solutions and industry-specific services. These advantages support logistics services provided by $\mathrm{KN}$ Indonesia for all factors, including aerospace, automotive, industrial and chemical goods, perishable, pharmaceutical and healthcare, project, oil and gas, marine (Production of Manufactured Goods/PROM), and Fast-Moving Consumer Goods (FMCG) and retail.

$\mathrm{KN}$ Indonesia has several branches spread in big cities on Java and Sumatra islands, such as Jakarta, Semarang, Surabaya, Medan, and Batam. It means that they can play an important role with a broad scope covering national and international Indonesian businesses. As part of the KN Group, which has led 125 years with 1.300 branch offices in 100 countries in managing the goods supply chain, $\mathrm{KN}$ Indonesia has become an experienced global leader.

KN Group's business growth is reasonably fast. In 2019, KN Group laid operational and financial foundations to further accelerate network expansion in Asia through organic and inorganic growth. The significant increase in the previous year was net turnover to CHF 21,1 billion (up 1,5\%) and gross profit to CHF 8,0 billion (up 3,5\%). Meanwhile, Earnings before Interest and Taxes (EBIT) reached CHF 1,1 billion (up 7,5\%), exceeding CHF billion for the first time. Earnings for the year raised 3,6\% at CHF 800 million. It proves that $\mathrm{KN}$ Group has a reasonably clear success rate and succeeds in becoming a significant driver of global economic development in the Asia Pacific region with a net turnover of CHF 2,5 billion $(11,7 \%)$ and contributing CHF 273 million $(25,7 \%)$ of EBIT.

Table 1 Competitiveness and Sustainability of 10 Cases

\begin{tabular}{|c|c|c|c|c|c|c|}
\hline Component & Factor & $\mathbf{K N}$ & DA & $\mathbf{P}$ & DB & $\mathbf{T}$ \\
\hline \multirow[t]{4}{*}{ Competitiveness } & Price & $\mathrm{x}$ & $\mathrm{x}$ & $\mathrm{x}$ & $\mathrm{x}$ & $\mathrm{x}$ \\
\hline & Services & $\mathrm{x}$ & $\mathrm{x}$ & $\mathrm{x}$ & $\mathrm{x}$ & $\mathrm{x}$ \\
\hline & People & $\mathrm{x}$ & & $\mathrm{x}$ & & \\
\hline & Network & $\mathrm{x}$ & $\mathrm{x}$ & $\mathrm{x}$ & $\mathrm{x}$ & \\
\hline \multirow[t]{2}{*}{ Sustainability } & Credibility & & $\mathrm{x}$ & $\mathrm{x}$ & $\mathrm{x}$ & \\
\hline & Innovation & $\mathrm{x}$ & $\mathrm{x}$ & & $\mathrm{x}$ & $\mathrm{x}$ \\
\hline Component & Factor & APL & $\mathbf{R}$ & AG & $\mathbf{F}$ & Ro \\
\hline \multirow[t]{4}{*}{ Competitiveness } & Price & $\mathrm{x}$ & & $\mathrm{x}$ & & $\mathrm{x}$ \\
\hline & Services & $\mathrm{x}$ & $\mathrm{x}$ & $\mathrm{x}$ & $\mathrm{x}$ & \\
\hline & People & $\mathrm{x}$ & $\mathrm{x}$ & $\mathrm{x}$ & & $\mathrm{x}$ \\
\hline & Network & $\mathrm{x}$ & & $\mathrm{x}$ & & \\
\hline \multirow[t]{2}{*}{ Sustainability } & Credibility & $\mathrm{x}$ & & & $\mathrm{x}$ & $\mathrm{x}$ \\
\hline & Innovation & $\mathrm{x}$ & $\mathrm{x}$ & & & \\
\hline
\end{tabular}

Note:

KN: Kühne + Nagel, DA: Damco, P: Panalpina, DB: DB Schenker, T: TNT Express, APL: APL Logistic, R: Rhenus Logistic, AG: Agility Logistics, F: FedEx, Ro: Röhlig Logistic 
The second case study is FedEx in Indonesia. FedEx Express Indonesia was established in 1985. Until nowadays, it has 941 workforces to serve the Indonesian market. FedEx Express Indonesia serves six big airports in four large islands of Java, Sumatera, Kalimantan, and Bali. In detail, the airports are Soekarno-Hatta International Airport in Jakarta, Hang Nadim International Airport in Batam, Kualanamu International Airport in Medan, Juanda International Airport in Surabaya, Sultan Aji Muhammad Sulaiman International Airport in Balikpapan, and I Gusti Ngurah Rai International Airport in Bali. FedEx Express has operated with 135 vehicles, B575 and B767 aircraft, and 173 drops off locations around Indonesia. However, FedEx Express had a considerable decline in its results in 2019. Net turnover decreased from US $\$ 4.572$ million in 2018 to US\$ 540 million in 2019. Then, revenue decreased from US\$2.348 million in 2018 to US\$1.159 million in 2019.

The third case study is Damco in Indonesia. Damco is a global freight forwarder offering Supply Chain Management (SCM) and sea and air freight services. The company manages supply chains for shippers from many industries, governments, and defense organizations. Damco holds 200 long-term contracts with an average length of three years. Before 2013, Damco has faced pressing performance challenges, including a relatively high overhead-togross margin ratio and a decline in freight-forwarding revenues.

As Damco's shortcoming in the logistics process, it does not have cross-regional cooperation or global standards. In 2013, Damco made improvements by restructuring its program globally by improving and expanding high-tech networks, consolidating locations, and optimizing operations. It carried out new regional structures to promote cross-regional collaboration, expand the number of offices, and limit the spread of locations. Not only that, but Damco also pressed logistics contracts in the dominant market and reduced the diversity of services to target e-commerce players. Damco did it to overcome the revenue from goods lost in transportation.

Another thing that Damco does is terminate the unprofitable contract. Since then, Earnings before Interest and Taxes, Depreciation and Amortization (EBITDA) has risen to US\$54 million. Damco has succeeded in increasing productivity, reducing overhead costs, and earning cash. SCM will play an essential role in the future.

The fourth case study is DB Schenker in Indonesia. Since 1976, PT Schenker Petrolog Utama has been active as a transport and logistics company in Indonesia, represented by DB Schenker. Since March 1999, DB Schenker has formed a joint venture with the Petrolog Indah Group for the long term. To be the first logistics provider to honor reliability and excellence is the glorious vision of PT Schenker Petrolog Utama. It has a reliable local partner with 500 employees in over 20 locations throughout Indonesia and branch offices in major cities, such as Jakarta, Tangerang, Semarang,
Surabaya, Medan, Batam, and Balikpapan to work. Transportation by air, sea, and land, rail freight, contract logistics, exhibition, relocation, project cargo, cargo insurance, and customs transportation are the focuses of DB Schenker in providing services. Besides, DB Schenker Indonesia also has certain country products, such as Denpasar Hub and Domestic Ocean Shipment.

The fifth case study is APL Logistics in Indonesia. Founded in 1977, APL Logistics is a global supply chain service provider with comprehensive services. It ranges from international freight forwarding services to and from destination and origin. It also handles the consolidation of freight forwarding, warehousing, and distribution management using innovative technology to provide efficiency, visibility, and maximum control. At present, APL Logistics has operated in more than 110 locations in 60 countries with the management of 200 logistics facilities. APL Logistics is led by a team of knowledgeable and competent professionals. It leads the management team of APL Logistics to global market knowledge that makes APL Logistics a trusted global logistics partner. APL Logistics has a broad focus and experience in four industrial sectors, namely automotive, consumer, industrials, and retail. APL Logistics Indonesia was founded in 1991 with various asset assets in three big cities, namely Jakarta, Semarang, and Surabaya. APL Logistics is identic with service quality, reliability, and operational excellence because it has a strong focus on providing high-quality services that can consistently meet and exceed the consumers' expectations.

The sixth case study is Panalpina in Indonesia. Panalpina is a Swiss-owned logistics company that provides shipping and logistics services specializing in intercontinental air and sea transportation and supply chain management solutions. At present, it operates with a network of 500 branches in more than 80 countries and more than 15.000 employees worldwide. It focuses on 12 core industries, including Hi-tech, automotive, telecom, retail and consumer, chemical, manufacturing, energy, healthcare, aerospace, government, perishables, and fashion. It also commits to pursuing business with integrity, respect for cultural differences, and individuals' dignity and rights in various countries. Moreover, it also has a concern for environmental sustainability and social responsibility by integrating these principles into its businesses. In Indonesia, Panalpina started in 1990. Today, based in Jakarta, Panalpina has branches in five cities, namely Surabaya, Semarang, Balikpapan, Medan, and Makassar, where local companies are appointed as official agents of Panalpina.

The seventh case study is Agility Logistics in Indonesia. Agility Logistics is a logistics company originating and based in Kuwait. It was founded in 1979 to provide freight forwarding, transportation, legislation, and supply chain management services for businesses, governments, international agencies, and aid agencies worldwide. At present, Agility Logistics has more than 22.000 employees and 500 offices in 100 countries. After the economic revival in the Middle East country, Agility Logistics has been a local warehousing provider 
company that becomes the largest logistics company in the Middle East. Growing and developing as the largest and most famous logistics company in the world, Agility Logistics can perform smart supply chain management services with technology in person to connect to its consumers' businesses to the global region. In addition to an extensive logistics network covering sea and air throughout Indonesia with the support of business partnerships with the world's leading operators, Agility Indonesia also has an Authorized Economic Operator (AEO) certification from the Indonesian Finance Ministry and the Directorate General of Customs and Excise.

The eighth case study is TNT Express in Indonesia. TNT Express is an international courier shipping service company founded in Australia in 1992 after World War II. It is also one of the largest express courier companies in the world. FedEx acquired it in 2016, which was a combination based on a competitive position in the global transportation and logistics industry. With headquarter in Hoofddorp, the Netherlands, TNT Express sends almost one million shipments every day, from documents and packages to pallet shipping. The company offers road and air shipping services in Europe, the Middle East, Africa, Asia-Pacific, and America. To ensure efficient service, TNT Express invests in developing its global computer system, improving a seamless delivery process through its network, and enabling optimal organizational solutions for transportation according to the needs. The services offered by TNT Express can be tailored to the customers' desires, ranging from fast courier services, courier services with the best prices, to special services that consumers can adjust.

The ninth case study is Röhlig Logistic in Indonesia. PT Rohlig Logistik Indonesia, better known as Röhlig Logistics, is a logistics forwarding company that offers a variety of solutions in the logistics process in the field of sea transportation, air transportation, projects, and logistics contracts. Röhlig Logistics is a family company founded in 1852 in Bremen, Germany. In Indonesia, Röhlig Logistics began to be established in 2017 to strengthen the independent network and serve customers better. Increased consumer interest in Indonesia and a shift in manufacturing centers from China to Southeast Asia and the Sub-Indian continent make Indonesia a primary emerging market.

In Indonesia, Röhlig Logistics has two branch offices in Jakarta and Surabaya, with two activities centered at Tanjung Priok Port, Jakarta, and Tanjung Perak Port, Surabaya, in addition to Röhlig Logistics' global network in more than 30 countries. Röhlig Logistics is committed to providing added value to its consumers' businesses by offering solutions that are specifically tailored to each customer's problems. Röhlig Logistics also has a very experienced team with high work standards. Having more than 2.000 employees in more than 30 countries makes the network of Röhlig Logistics very broad. Röhlig Logistics also specializes in achieving optimal organization and complex logistical processes.
The tenth case study is Rhenus Logistic in Indonesia. Rhenus Logistics is a global logistics services company with operations in more than 600 locations worldwide with around 29.000 employees. Rhenus Logistics has four primary logistics services: contract logistics, shipping logistics, port logistics, and public transportation. Rhenus Logistics can manage complex supply chains and create more value through innovative value-added services. Rhenus Logistic always looks forward so that logistical operations carried out can make essential contributions.

In Indonesia, Rhenus Logistic opened Rhenus Project Logistics Indonesia in 2015 with the leading service of the cargo project. Rhenus Project Logistic Indonesia is part of the global Rhenus Logistic, intending to add value to projects carried out by its consumers. Rhenus Logistic offers comprehensive project solutions tailored to the specific needs of the project. Project services include acceleration, land, sea, and air transportation, customs, and shipping to the project site.

Next, it is about the condition of LSP in Indonesia. The logistics market competition in Indonesia is arguably still dominated by foreign companies. It is because Indonesian local logistics companies do not have enough competitiveness to compete with foreign logistics companies. However, some variables can make local companies more competitive compared to foreign logistics companies. First, because of its market share in Indonesia, local logistics companies from Indonesia should have more knowledge about the conditions and challenges encountered in running their companies. Second, the existence of government regulations indirectly makes it easier to establish local logistics companies. Through the Coordinating Board of Republic Indonesia Investment regulation No. 6, 2018, concerning Program and Procedures for Licensing and Investment Facilities, the government requires foreign companies to have wealth or investment with the amount of Rp10.000.000.000,00 excluding land and buildings for businesses.

Moreover, the barrier in operating an LSP in Indonesia can be influenced by two key factors, which are internal factors and external factors. Based on the interviews with informants, these external factors are influenced by the government's role, starting from government-made regulations, including customs clearance, infrastructure, and economic conditions that are not evenly distributed in Indonesia. Meanwhile, internal factors are influenced by the capital and capabilities of the providers in providing logistics services to consumers. The statements by the informants can be seen as follows.

"Barrier in Indonesia for external obstacles are more challenging. Many of the obstacles start from the ever-changing regulations" (DY)

"The second is the lack of neat existing infrastructure, let alone talking about one island, other than the island of Java" (BY) 
"Then the economy is not evenly distributed. Our economy is not evenly distributed" (AP)

"For internal barriers, the most difficult at first, yes, it is the competence of people in providing the best service to the customer. The second is capital. The capital is huge for a foreign company where the funds that are saved and not contested are US\$2 million" (BS)

Then, the success of LSP can be achieved by understanding the consumers' needs for these logistics services. The success factor includes three main things: the need for providing logistics services with a suitable and effective supply chain process for consumers, knowing the main purpose of consumers in using logistics services, and understanding the behavior of consumers based on their history. Moreover, factors that can build the competitiveness of LSP based on the results of interviews are price, services, human resources (people), and network. Consumers of logistic services in Indonesia usually require inexpensive service prices with fast service. Because consumers desire cheap service prices, they will tend to compare the prices of each LSP. Therefore, competitive prices are needed, so companies can be chosen by consumers and have competitiveness compared to the competitors. This factor is proven by the excerpt from the interview, as seen in Table 2.
Service is the main product of LSP. In this industry, companies are required to provide the best service as the key to having a sustainable competitive advantage. Based on the results of interviews (See Table 3), the services provided must cover three main aspects. First, it is service quality that the provided services must have high-quality standards. Second, the provider's ability to adjust its condition to market conditions and consumers' will. Third, there must be service differentiation. Services provided by logistic service companies must have good service quality with standards. The quality of this new service can provide many positive effects, such as reducing operating expenses. In addition, the quality of services can be a differentiator between one provider and other providers.

People or provider-owned human resources have essential factors in the competitive advantage of sustainability. In this case, LSP must ensure that the resources owned have good quality and good relationships with the consumers. The companies can invest in their human resources through training and strengthen their teams by providing knowledge and conducting periodic evaluations through provider attributes, such as Standard Operating Procedures (SOPs) and Key Performance Indicators (KPIs). These efforts can maintain a good and stable quality of human resources. This factor is proven by the excerpt from the interview, as shown in Table 4.

Table 2 Interview Excerpt on Cost

\begin{tabular}{ll}
\hline Interview Excerpt & $\begin{array}{l}\text { "So far, as far as I know, their behavior is related by their habit of comparing } \\
\text { prices, if I see it." }\end{array}$ \\
Informant & $\mathrm{SM}$ \\
Interpretation & $\begin{array}{l}\text { The competitiveness factor of LSP is price. Consumers tend to compare } \\
\text { prices between LSP. }\end{array}$ \\
Code & Competitiveness; Cost; Comparing Prices \\
\hline
\end{tabular}

Table 3 Interview Excerpt on Service

Interview Excerpt $\quad$ "So, if you ask our two competitors and us, it is basically the same service.
When we talk about service, there are some things we can improve. We can
make a differentiation on what we offer, what we can, and what we cannot
and do not want."

Informant

Interpretation

\section{BS}

In general, the services offered by logistic service providers are the same. However, there are some services that the companies can improve, change, or differentiate more compared to similar services offered by other companies. 


\begin{tabular}{ll}
\hline Interview Excerpt & "Then, the other important thing is people as competitiveness, especially \\
in the field of sales or operations. Moreover, it is yes. We really train and \\
educate our people to meet the best quality according to our standards." \\
(BS) \\
"... for the customers, the price is yes, but it is also where they feel \\
comfortable with the staff. The relationship is how we get to know the \\
customer and how the customer trusts us." (IJ) \\
RN, BS, IJ, DY \\
The quality of human resources becomes a competitive factor in LSP. \\
Moreover, building a good relationship with customers can make them \\
comfortable to maintain competitiveness owned by the company. \\
Interpretation \\
Competitiveness; People; Quality; Relationship \\
Code \\
Interpretation \\
Table 5 Interview Excerpt on Service \\
Code \\
certain factor is usually cost first, and the other is service quality." (YS) \\
RN, BS, YS, DY \\
The services provided by logistics service companies must have standards \\
so that the services provided can continue to have high quality. \\
Competitiveness; Service; Differentiation
\end{tabular}

Logistics service companies are required to continue to develop networks and partners. With network development and partners, many companies can have the benefits of serving all consumers from all segments and have an efficient logistics process. This factor is proven by the excerpt from the interview, as seen in Table 5.

There are two factors to maintain the competitiveness of logistics services and become sustainable. Those factors are innovation and credibility of LSP. Innovation will enhance the competitiveness toward its sustainability in LSP. Logistics service companies are obliged to continue to provide innovation in terms of system updates and newly offered services that can solve problems faced by consumers. Companies can innovate to keep improving and being in line with the market developments and continuing to increase customer satisfaction. In addition, innovation can also provide new competitiveness and become a differentiator between logistics services companies. This factor is discussed by YS and is supported by IJ, RN, DA, AP, and AF. The interview excerpt can be seen as follows.

"... but at the end of the day, innovation is in front of it. Why do I say that, it is supposed to maintain competitiveness and even strengthen it to become a sustainable factor in LSP"
Credibility is a factor that also amplifies the competitiveness effect of LSP toward sustainability. Brand image, expertise, trust, and commitment are four things that represent the credibility factor of an LSP. Brand image means the image of the company. Then, expertise is how reliable the company is in dealing with problems that may arise in providing services to customers. It is also defined as how service delivery experience can be applied and become learning for the provision of services to other customers. The logistics service companies' commitment to service level can positively impact the credibility of the company. It is elaborated by SM and supported by DA, YS, BS, RY, and DY as follows.

“... So, credibility is the first factor to sustain its competitiveness. Credibility is a brand that is more about brand image. After that, there are the expertise of the staff in providing the service, the courage to perform the service, and so on."

The findings show different factors that construct the competitiveness of LSP in previous research (Zaroni, 2017). In the research, the result on competitiveness factors of LSP is service, people, and network. Meanwhile, the price factor is relevant to Zaroni (2017). The research also extends the competitiveness of LSP to sustainability that is moderated by innovation and credibility. Those 


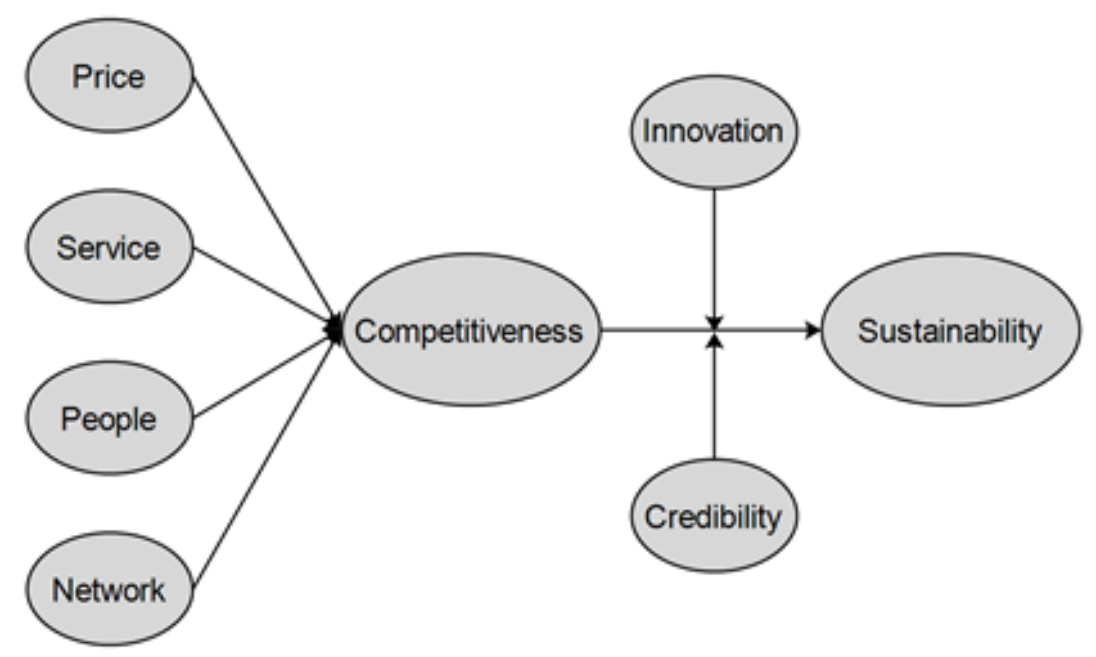

Figure 1 Model Finding

factors can amplify the competitiveness factor toward sustainability. Moreover, the research complements and fills the research gap on service and price variables identified by Karia, Assari, and Wong (2014), who showed that there were four major factors to create and maintain competitiveness: relation (network), organization, knowledge (people), and technology and physique. For practical implications, besides price and people, 3PL needs to improvise on creating service value that consumers need and develop the point-topoint network to enhance their competitiveness.

A research model is developed based on the findings of interviews and an analysis of the factors influencing the competitiveness and sustainability of foreign 3PLs, as shown in Figure 1. Price, service, people, and network are the four main factors influencing the emergence of competitiveness in 3PL. The credibility built by the company and the innovation of the company's services must be strengthened to increase the competitiveness of 3PLs so that it becomes a sustainable business.

\section{CONCLUSIONS}

Four factors that influence the competitiveness of LSP are costs, services, people, and networks. Efficient and competitive costs for the same services increase competitiveness, flexible services, and the end-toend solution (comprehensive solution) to markets and consumers' needs. Then, skilled human resources with the ability to acquire and maintain good relationships with consumers and suppliers and extensive business networks will enhance its competitiveness. Moreover, two additional factors enhance the influence to retain its sustainability. Those factors are innovation and credibility of the provider. Continuous innovations on all business functions in infrastructure, service innovation, and facility (warehouses) and credibility over a brand image (sufficient commitment) to always provide the best service are required to maintain the competitiveness sustainability.

The limitation of the research is the limited informant. So, the extension of foreign 3PLs to local 3PLs can be done for further research. Moreover, the method used is qualitative to deepen the result, but it needs to be justified using other methods that can apply the research model. It can add insight to stakeholders about the lack of role and view of the government as a regulator in this LSP-related regulation. Moreover, following the findings of the sustainability model and competitiveness of LSP described in Figure 1, it can provide opportunities for further research on the relationship and influence of these variables on other similar companies in various countries. Therefore, it will contribute to the development of science in the logistics field.

\section{REFERENCES}

Alshawi, S. (2001). Logistics in the Internet age: Towards a holistic information and processes picture. Logistics Information Management, 14(4), 235-242. https:// doi.org/10.1108/EUM0000000005718

Allied Market Research. (2020). Third-party Logistics (3PL) market statistics - 2027. Retrieved from https://www. alliedmarketresearch.com/3PL-market

Aziz, Z. A. (2017). The relationship between resource, capability, innovation, logistics performance, and competitive advantage (Doctoral thesis). Universiti Malaysia Kelantan.

Bienstock, C. C., Royne, M. B., Sherrell, D., \& Stafford, T. F. (2008). An expanded model of logistics service quality: Incorporating logistics information technology. International Journal of Production Economics, 113(1), 205-222. https://doi. org/10.1016/j.ijpe.2007.03.023 
Burnson, P. (2017). Armstrong \& Associates 2017 top 50 U.S. and global third-party logistics providers. Retrieved from https://www.supplychain247. com/article/2017_top_50_us_global_third_party_ logistics_providers

Cavaignac, L., Dumas, A., \& Petiot, R. (2020). Third-party logistics efficiency: An innovative two-stage DEA analysis of the French market. International Journal of Logistics Research and Applications, 1-24. https:// doi.org/10.1080/13675567.2020.1784117

Choi, D., \& Song, B. (2018). Exploring technological trends in logistics: Topic modeling-based patent analysis. Sustainability, 10(8), 1-26. https://doi.org/10.3390/ su10082810

Daugherty, P. J., Stank, T. P., \& Ellinger, A. E. (1998). Leveraging logistics/distribution capabilities: The effect of logistics service on market share. Journal of Business logistics, 19(2), 35-51.

Ding, M. J., \& Jie, F. (2021). The moderating effect of Guanxi on supply chain competencies of logistics firms in China. International Journal of Logistics Research and Applications, 24(4), 407-425. https://doi.org/10 $.1080 / 13675567.2020 .1763280$

Ellinger, A. E., Ketchen Jr, D. J., Hult, G. T. M., Elmadağ, A. B., \& Richey Jr, R. G. (2008). Market orientation, employee development practices, and performance in logistics service provider firms. Industrial Marketing Management, 37(4), 353-366. https://doi. org/10.1016/j.indmarman.2007.01.002

Elzarka, S. (2020). A study on engaging employees in adopting green logistics practices: The case of logistics service providers in Egypt. International Journal of Logistics Systems and Management, $37(1), 140-152$.

Fabregas, K. (2018). 3PL definition \& how third party logistics companies work. Retrieved from https:// fitsmallbusiness.com/3pl-definition-third-partylogistics/

Gong, F., Kung, D. S., \& Zeng, T. (2018). The impact of different contract structures on IT investment in logistics outsourcing. International Journal of Production Economics, 195, 158-167. https://doi. org/10.1016/j.ijpe.2017.10.009

Gunasekaran, A., \& Ngai, E. W. T. (2003). The successful management of a small logistics company. International Journal of Physical Distribution \& Logistics Management, 33(9), 825-842. https://doi. org/10.1108/09600030310503352

Huo, B., Wang, Q., Zhao, X., \& Hua, Z. (2017). Barriers to third-party logistics integration: Empirical evidence from China. Industrial Management \& Data Systems, 117(8), 1738-1760. https://doi.org/10.1108/ IMDS-08-2016-0344

Indonesia Economic Forum. (2020). Indonesia logistics market revenues forecast, 2020-2024. Retrieved from https://www.indonesiaeconomicforum. com/indonesia-logistics-market-revenuesforecast-2020-2024/
Jha, P. C., Aggarwal, R., \& Singh, S. P. (2020). Studying the interrelationship between third party logistic service provider enablers using ISM methodology. Journal of Modelling in Management, 15(1), 182-200. https:// doi.org/10.1108/JM2-09-2018-0132

Karia, N., Asaari, M. H. A. H., \& Wong, C. Y. (2014). Exploring the comprehensive framework of thirdparty logistics providers competitive advantage: A resource-based view approach. Australian Journal of Basic and Applied Sciences, 8(23), 345-351.

Langley Jr, C. J. (2019). 2019 Third-party logistics study: The state of logistics outsourcing. Retrieved from https://www.kornferry.com/content/dam/kornferry/ docs/article-migration/2019-3PL-Study.pdf

Langley Jr., C. J., Van Dort, E., Morton, J., Hoemmken, S., Goh, A., Zabawa, M., Strata, R., \& Riegler, M. (2007). The state of logistics outsourcing: 2007 third-party logistics. Retrieved from https:// archive.sap.com/kmuuid 2/40021f7d-7de 7 2a 10-80a 1-8318686444a9/2007\%20ThirdParty\%20Logistics\%3A\%20Results\%20and\%20 Findings \%20of\%20the \%2012th\%20Annual\%20 Study.pdf

Lestarini, A. H. (2021). Bisnis logistik melejit sejak pandemi. Retrieved from https://www.medcom.id/ekonomi/ ekonomi-digital/VNxvORdk-bisnis-logistik-melejitsejak-pandemi

Miles, M. B., Huberman, A. M., \& Saldana, J. (2013). Qualitative data analysis: A methods sourcebook. SAGE Publications.

Min, H., \& Jong Joo, S. (2006). Benchmarking the operational efficiency of third party logistics providers using data envelopment analysis. Supply Chain Management, 11(3), 259-265. https://doi. org/10.1108/13598540610662167

Myers, M. B., Griffith, D. A., Daugherty, P. J., \& Lusch, R. F. (2004). Maximizing the human capital equation in logistics: Education, experience, and skills. Journal of Business Logistics, 25(1), 211-232. https://doi. org/10.1002/j.2158-1592.2004.tb00175.x

Panayides, P. M. (2007). Effects of organizational learning in third-party logistics. Journal of Business Logistics, 28(2), 133-158. https://doi. org/10.1002/j.2158-1592.2007.tb00061.x

The World Bank. (2018). Global rankings 2018. Retrieved from https://lpi.worldbank.org/international/ global $/ 2018$

Uvet, H. (2020). Importance of logistics service quality in customer satisfaction: An empirical study. Operations and Supply Chain Management: An International Journal, 13(1), 1-10. http://doi. org/10.31387/oscm0400248

Zaroni. (2017). Daya saing perusahaan penyedia jasa logistik nasional. Retrieved from https:// supplychainindonesia.com/daya-saing-perusahaanpenyedia-jasa-logistik-nasional/ 